\title{
Intercircuit Conflicts and the Enforcement of Extracircuit Judgments
}

\author{
Laurie R. Wallach
}

When a litigant seeks to enforce a Gircuit A judgment in Circuit B, which would interpret the law at issue in the opposite way, Circuit B faces a dilemma. If Circuit B followed the principle of full faith and credit $^{1}$ and honored the Circuit $\mathrm{A}$ judgment as res judicata, ${ }^{2}$ the conflicting Circuit $A$ and $B$ interpretations would then be enforced simultaneously within a single jurisdiction; the appropriate law would be deter-

1. "Full faith and credit" is a constitutional principle:

Full Faith and Credit shall be given in each State to the public Acts, Records, and judicial

Proceedings of every other State. And the Congress may by general Laws prescribe the Man-

ner in which such Acts, Records and Proceedings shall be proved, and the Effect thereof.

U.S. CoNST. art. IV, $\S 1$. Congress exercised the power granted it by this clause as early as 1790 by enacting a federal statute that gave appropriately authenticated state judgments the same faith and credit they would have in the courts of the rendering state. Radin, The Authenticated Full Faith and Credit Clause: Its History, 39 ILL. L. REv. 1, 10-11 (1944). The current version of this statute, 28 U.S.C. $\$ 1738$ (1982), extends full faith and credit to all courts and territories of the United States. See infra note 18.

2. The terminology for rules of preclusion has long confused students of law largely because "res judicata" has both a general and a specific technical meaning. It refers generically to the common law principles of precluding relitigation either of claims or of issues determined at a prior proceeding between the same parties. Its purpose is generally described as threefold: it puts an end to litigation; it conserves judicial resources and limits costs to private litigants; and it fosters reliance on the judicial system by avoiding inconsistent judgments that might result from relitigation. See $18 \mathrm{C}$. WRIGHT, A. Miller \& E. Cooper, Federal Practice and Procedure § 4403 (1981) [hereinafter cited as C. WRIGHT].

The term "res judicata" also refers specifically to claim preclusion, which bars relitigation of a cause of action after a final judgment regardless of whether all grounds or defenses were judicially determined. By contrast, issue preclusion, also referred to as "collateral estoppel," bars relitigation of issues or matters already determined. RESTATEMENT (SECOND) OF JUDGMENTs § 17 comment c (1980); Commissioner v. Sunnen, 333 U.S. 591, 597-98 (1948). The Restatement (Second) of Judgments has moved to abandon the common law terminology in favor of the phrases "claim preclusion" and "issue preclusion." In this Note, "res judicata" will be used only to refer to its generic meaning of rules that preclude relitigation; "issue preclusion" and "collateral estoppel" will be used interchangeably.

Traditionally, litigants could invoke res judicata only against parties to the original suit. Caselaw of the last decade, however, has eroded this so-called "mutuality" requirement, at least when applying collateral estoppel. The Supreme Court recently enunciated a rule of nonmutual collateral estoppel that disallows relitigation of an issue even against a different party. Parklane Hosiery Co. v. Shore, 439 U.S. 322, 326-28 (1979). Now litigants may invoke collateral estoppel from either an offensive or a defensive posture against a private party who has litigated the issue with another adversary and lost. Special rules apply, however, in litigation against the federal government. See infra text accompanying notes 60-63. See generally United States v. Mendoza, 464 U.S. 154, 159-64 (1984) (doctrine of nonmutual collateral estoppel cannot be invoked against federal government).

Because this Note focuses exclusively on enforcing judgments between parties to the original litigation, it will use the term "res judicata" to refer to the traditional doctrine requiring mutuality of parties. 
mined by the litigant's identity ${ }^{3}$ rather than geographic location. If Circuit $B$ observed only its internal law, on the other hand, stare decisis ${ }^{4}$ would require that the Circuit $\mathrm{A}$ judgment be modified according to Circuit $\mathrm{B}$ precedent; Circuit B would then disregard full faith and credit and the same litigants would be subject to different rules of federal law according to their geographic location.

This example dramatizes the tension in the intercircuit arena between the two theoretical principles informing enforcement of judgments: the notion of jurisdictional boundaries that delimit and define a sovereign's power, and full faith and credit, which expands that power by making judgments portable. These concepts, derived from the international law principles of territoriality and comity, ${ }^{5}$ govern the obligations between states in enforcing one another's judgments. Their application to the federal circuits, however, raises practical problems. Circuits lack the executive and legislative attributes of sovereignty that make jurisdictional boundaries meaningful; yet, though they are merely arms of a single sovereign, they enjoy independence from one another when interpreting matters of federal law. "The unique status of circuits-something "less" sovereign than states but "more" than mere coordinate courts-generally has no effect on the balance preserved between full faith and credit and jurisdictional boundaries. That balance is upset when the intercircuit enforcement of judgments tests the relationship between federal circuits-that is, when circuits with conflicting interpretations of federal law are asked to enforce one another's judgments construing those laws. ${ }^{7}$ The national scope of modern federal litigation, particularly litigation initiated by federal agencies, coupled with the perennial regeneration of intercircuit con-

3. That identity is determined, in turn, by the circuit in which the litigant happened to have obtained her original judgment.

4. Stare decisis is a common law rule that governs a court's obligation to follow precedent. The rule requires a court generally to follow its own decision in future cases. 1B J. MOORE, J. LuCAS \& T. Currier, Moore's Federal Practice II 0.401-0.402 (2d ed. 1984). Stare decisis also binds lower courts to decisions of higher courts to which they owe obedience. See, e.g., Allegheny Gen. Hosp. v. NLRB, 608 F.2d 965, 969-70 (3d Cir. 1979) (stare decisis requires administrative agency to follow prior high court ruling).

5. Justice Story uses the term "comity" to describe the wholly voluntary nature of one nation's recognition of another nation's judgments. J. STORY, COMMENTARIES ON THE Conflict OF LAwS 32-33 (7th ed. Boston 1872) (1st ed. Boston 1834). The word "comity" derives from "comitas" or "courtesy," indicating that the doctrine's force stems from social or diplomatic rather than legal pressures.

6. See infra text accompanying notes 25-26 and note 26 .

7. This Note is concerned with the enforcement between circuits of judgments based upon federal law. The important question of intercircuit enforcement of diversity judgments raises different questions and lies beyond the scope of this undertaking. For an example of the problems in intercircuit enforcement of diversity judgments, see Williams v. Ocean Transp. Lines, Inc., 425 F.2d 1183 (3d Cir. 1970); Professor Degnan critiques the court's analysis in Williams in Degnan, Federalized Res Judicata, 85 YALE L.J. 741, 765-67 (1976). 
flict, ${ }^{8}$ calls for a clearly articulated rule defining the preclusive effect circuits should afford federal judgments on matters of federal law. ${ }^{\circ}$

This Note traces the history of full faith and credit and describes the tension between this principle and that of jurisdictional boundaries as they apply to the unique structure of the federal circuits. Based on analysis of the structure and interaction of the federal circuits, this Note proposes a rule of intercircuit enforcement designed to accommodate simultaneously the fundamental purpose of res judicata-the avoidance of repetitious litigation-and the judicial policy goal of ensuring each circuit's control within its boundaries. The proposed rule generally favors enforcement, but permits an enforcing circuit to modify a judgment between the original parties when a suit between different parties in the enforcing circuit creates a conflict with the extracircuit judgment.

\section{The Problem}

The full faith and credit clause gives national effect to state judicial and legislative acts by requiring recognition beyond a state's borders of local judgments and laws. Because federal circuit courts have judicial independence in interpreting matters of federal law, they also need a rule requiring that their judgments be given credit in other circuits. Paradoxically, even as it gives force to judicial integrity, the mandated recognition of extraterritorial judgments-judgments rendered in a different jurisdiction-necessarily encroaches on the integrity of courts and uniform treatment of litigants in the enforcing jurisdiction. This paradox raises serious problems primarily in the context of the federal circuits, which, in contrast to states, interpret a single set of laws.

8. The "problem" of intercircuit conflicts has attracted much attention in the last decade. The size of the Supreme Court docket, coupled with the differential treatment of litigants across the country, has sparked much debate and many proposals for reform. Chief Justice Burger, a prominent advocate of an intermediate appellate tribunal, has thrown the issue of intercircuit conflicts into even sharper relief. Burger, The Time is Now for the Intercircuit Panel, 71 A.B.A. J. 86 (1985) [hereinafter cited as Intercircuit Panel]; Burger, Annual Report on the State of the Judiciary, 69 A.B.A. J. 442 (1983) [hereinafter cited as Annual Report]. For a general overview of the proposals and debates surrounding this problem, see Estreicher \& Sexton, A Managerial Theory of the Supreme Court's Responsibilities: An Empirical Study, 59 N.Y.U. L. REv. 681, 684-704 (1984); New York University Supreme Court Project, 59 N.Y.U. L. REv. 677 (1984). See also infra note 29 (outlining proposals for an intermediate appellate court).

9. This Note is concerned with the res judicata effect of judgments on matters of law rather than matters of fact. Both claim and issue preclusion bear on that effect. Claim preclusion applies when a single cause of action gives rise to a judgment the parties seek to enforce outside the rendering jurisdiction. Issue preclusion applies when, in a separate proceeding arising from a different cause of action, a party seeks to enforce an issue determined in a prior lawsuit. This distinction blurs when the same problem arises from identical but separate facts in a second jurisdiction. The definition of the "cause of action" ultimately determines whether a claim or an issuc is at stake. 


\section{A. Full Faith and Credit}

The concepts of jurisdictional boundaries and full faith and credit have their roots in two principles of international law: territoriality and comity of nations. These principles, working in tandem, have historically defined the obligations between nation-states. The force of one nation's laws extends only to its territorial limits, binding all subjects within it, temporary and permanent residents alike; but under comity or courtesy, nations give effect to foreign laws provided the laws do not prejudice national rights and interests. ${ }^{10}$

\section{The States}

The framers chose to elevate the practice of comity between nationstates to a constitutional mandate regulated by Congress. Through the full faith and credit clause of the Constitution and its predecessor, the Fourth Article of Confederation, ${ }^{11}$ they gave "each State a higher security and confidence in the others, by attributing a superior sanctity and conclusiveness to the public acts and judicial proceedings of all."12 Since 1790, Congress has exercised the power this clause grants by giving state judgments the same faith and credit they would have in the rendering state. ${ }^{13}$

10. These principles of comity and jurisdictional boundaries need not conflict because comity confers neither rights nor requirements but merely a "[duty of] imperfect obligation, like that of beneficence, humanity, and charity. Every nation must be the final judge for itself, not only of the nature and extent of the duty, but of the occasions on which its exercise may be justly demanded." J. STORY, supra note 5 , at 29.

11. The Fourth Article of Confederation devoted three paragraphs to describing and directing the relations between the states. The first paragraph governed rights of citizens between states, the second provided for extradition of criminals between states, and the final paragraph introduced "full faith and credit": "Full faith and credit shall be given in each of these states to the records, acts and judicial proceedings of the courts and magistrates of every other state." ARTICles OF Confederation, ART. IV, reprinted in Documents of AMERICAN History 111 (H. Commager ed. 8th ed. 1968).

12. J. Story, 2 Commentaries on the Constitution of the UNITED States 190 (5th ed. Boston 1891) (1st ed. Boston 1833).

13. Prior to the ratification of the Articles of Confederation, the states owed one another the same faith and credit ordinarily conceded to foreign judgments under principles of comity. J. STORY, supra note 5 , at 754 n.4; J. STORY, supra note 12, at 189-90.

The practical effect the framers intended to give the full faith and credit clause is not entirely clear from records of its passage. The clause grants Congress power to determine the content given the words "full faith and credit." During the debates of the Federal Convention, one speaker noted the potential for abuse left open by this language: "Mr. Randolph considered it as strengthening the general objection agst. [sic] the plan, that its definition of the powers of the Government was so loose as to give it opportunities of usurping all the State powers." 2 THE REcords OF THE FEDERAL Convention of 1787, at 488-89 (M. Farrand ed. 1966). The clause was passed, this objection notwithstanding, with a "gestation" period of less than five days. R. JACkson, Full FATTH AND Credit: The Lawyer's Clause of the Constitution 5 (1945).

Congress seems consistently to have interpreted the clause to mean that states must give extraterritorial judgments the effect they have in the rendering state. See supra note 1 . Presumably, however, the second half of the full faith and credit clause grants Congress the power to define the phrase as it sees fit, and to alter that definition when it chooses. Several different meanings might be attributed to the words "full faith and credit." For example, the enforcing state might be required to give an 
The full faith and credit clause thus makes possible the coexistence of independent states in a single nation. First, it affirms the integrity of independent state judiciaries: the guarantee that a party cannot evade enforcement of a judgment by leaving the rendering forum gives force to the exercise of judicial power. Second, the clause "alter[s] the status of the several states as independent foreign sovereignties, each free to ignore obligations created under the laws or by the judicial proceedings of the others, and ... make[s] them integral parts of a single nation ... . "14 Parties to a lawsuit, having adjudicated their rights in any state, can enforce those rights nation wide. ${ }^{15}$ Third, full faith and credit eliminates the waste and injustice of unnecessary relitigation: in giving national effect to judgments rendered in a single jurisdiction, it also gives national effect to rules of res judicata. ${ }^{16}$

\section{The Federal Circuits}

Just as states need a rule of recognition of judgments to protect the force of their judicial pronouncements, so circuits, with their judicial independence, require such protection. Without it, litigants could evade an unfavorable circuit judgment simply by leaving the jurisdiction. ${ }^{17}$ Section

extraterritorial judgment only the effect of its own comparable judgments or it might be required to give the judgment mere evidentiary value in a new proceeding. See generally Degnan, supra note 7, at 742 n.5 (citing literature discussing the evolution of the constitutional concept of full faith and credit).

14. Milwaukee County v. M.E. White Co., 296 U.S. 268, 277 (1935) (judgment for tax liability entitled to full faith and credit).

15. Magnolia Petroleum Co. v. Hunt, 320 U.S. 430 (1943), gives quintessential expression to the principle of full faith and credit:

[T]he clear purpose of the full faith and credit clause [was] to establish throughout the federal system the salutary principle of the common law that a litigation once pursued to judgment shall be as conclusive of the rights of the parties in every other court as in that where the judgment was rendered, so that a cause of action merged in a judgment in one state is likewise merged in every other. The full faith and credit clause like the commerce clause thus became a nationally unifying force.

Id. at 439.

16. Full faith and credit limits litigation because "[m]atters once decided between adverse parties in any state or territory are at rest," and adversaries cannot "wage again their legal battles whenever they me[e]t in other jurisdictions." Riley v. New York Trust Co., 315 U.S. 343, 348-49 (1942). At the time of the Constitutional Convention, national recognition of res judicata was essential because it could scarcely consist with the peace of society, or with the interest and security of individu-

als, with the public or with private good, that questions and titles, once deliberately tried and decided in one State, should be open to litigation again and again, as often as either of the parties, or their privities, should choose to remove from one jurisdiction to another.

J. STORY, supra note 12 , at 190.

Full faith and credit, however, does not establish specific rules of preclusion; rather, it gives local rules of res judicata national effect. Full faith and credit requires an enforcing state to afford a judgment the credit to which it is entitled in the rendering state. The res judicata rules of the rendering state dictate that degree of credit.

17. Obviously, because circuits are already part of a unitary system, they have no need to be "unified" by full faith and credit. But they do benefit from the other two effects of that principle-the protection of judicial integrity and the elimination of unnecessary relitigation. 
1738 of 28 U.S.G. ${ }^{18}$ extends full faith and credit to the federal courts. This statute regulates federal court enforcement of two sets of judgments: those of other federal courts and those of states. This Note is concerned with only the first category-the treatment by federal courts of judgments from other federal courts.

\section{B. The Enforcement of Judgments Across Jurisdictional Boundaries}

"One of the most fundamental social interests is that law shall be uniform and impartial."19 Uniformity promotes the twin goals of equity and judicial integrity-similar treatment of similar litigants secures equity, while it also inspires confidence in the legal system, a confidence crucial to the effective exercise of judicial power. Thus, "[i]t will not do to decide the same question one way between one set of litigants and the opposite way between another." ${ }^{20}$ The enforcement ${ }^{21}$ of extraterritorial judgments

18. 28 U.S.C. $\S 1738$ (1982), sometimes referred to as the "Federal Res Judicata Act," C. WRIGHT, supra note $2, \S 4467$, at 627 , provides:

Acts, records and judicial proceedings or copies thereof, [appropriately] authenticated, shall have the same full faith and credit in every court within the United States and its Territories and Possessions as they have by law or usage in the courts of such State, Territory or Possession from which they are taken.

Most cases concerning 28 U.S.C. $\S 1738$ confront a problem beyond the scope of this Note-the complex relationship between state and federal courts, in particular the treatment by federal courts of state court judgments. See, e.g., Kremer v. Chemical Constr. Corp., 456 U.S. 461, 466 (1982) (28 U.S.C. § 1738 requires federal courts to give state court judgments the same preclusive effect they would have in state's own courts).

Though the question at issue here-the precise effect of this statute on the respect required of federal courts toward one another's judgments-remains a matter of some contention, C. WRIGHT, supra note $2, \S 4466$, at $618-22$, persuasive scholarship urges the acceptance of a rule that any judgment, whether state or federal, should be given full faith and credit in any court. Degnan, supra note 7, at 755-73. Moreover, Professor Degnan, tracing the history of res judicata in federal courts, argues convincingly that federal rules of preclusion should govern decisions of federal law. Currently, the sources of these rules vary. Provisions in the Federal Rules of Civil Procedure that speak of preclusive effects of federal adjudication, such as Rule 41(b) providing for dismissal "with prejudice," or Rule 23 binding all members of a class to a class action suit, provide some authority, id. at 761-63, as do the few federal statutes that specify res judicata effect. C. WRIGHT, supra note $2, \S 4403$, at 19 n.20 (listing statutes). But these authorities answer only a few specific questions about preclusion and do not provide courts with a general rule of res judicata.

Caselaw has increasingly filled the gaps in authority. For example, the federal courts have developed the new doctrine of nonmutual collateral estoppel. Degnan, supra note 7, at 763-69; see supra note 2. This method of developing rules of federal res judicata comports with the function as well as the history of the judge-made principle of preclusion. REsTatemEnT (SECOND) OF JuDGMENTs 5-6 (1980).

19. B. Cardozo, The Nature of the Judicial. Process 112 (1921).

20. Id. at 33 .

21. The Restatement (Second) of Conflict of Laws distinguishes "enforcement" from "recognition":

A foreign judgment is recognized, as the term is used in the Restatement of this Subject, when it is given the same effect that it has in the state where it was rendered with respect to the parties, the subject matter of the action and the issues involved. A foreign judgment is enforced when, in addition to being recognized, a party is given the affirmative relief to which the judgment entitles him. Recognition of a judgment is a condition precedent to its enforcement. Restatement (SECOND) of CoNflict of LAws 277 introductory note on recognition of foreign 
necessarily encroaches on these values in both the interstate and intercircuit contexts.

\section{Interstate Enforcement}

As sovereigns with legislative and executive independence, states develop and administer distinct and often different sets of laws. When State A enforces a State B judgment that conflicts with State A law or policy, the enforcement of law in State A ceases to be uniform. ${ }^{22}$ This lack of uniformity, which subjects different parties in a single state to two different sets of laws, raises the specter of inequitable treatment. Similarly, because State A must enforce the State B judgment, litigants can deliberately obtain that judgment in order to insulate themselves from State A's laws. Such forum shopping undermines the integrity of both states by undermining their ability to administer their own laws within their own borders. $^{23}$

As long as the volume of these out-of-state judgments remains small and litigants do not regularly use them to evade State A's laws, however, the lack of uniformity poses no serious threat to State A's control over its territory or to its courts' evenhanded treatment of litigants. ${ }^{24}$ The interstate enforcement of judgments finds an analogue in choice-of-law

judgments (1969). For the purposes of this Note, the terms "enforcement" and "recognition" will be used interchangeably.

22. Of course, if both states have the same law-for example, they have both adopted a uniform code-then this problem does not exist.

23. Under these circumstances, the full faith and credit statute may actually thwart its own purpose. The rendering forum exerts influence beyond its limits; the enforcing forum cannot control the law within its borders. Thus, for example, decisions often affect parties beyond the territory of the rendering state and may require the enforcing state to recognize a judgment at odds with its public policies. See, e.g., Williams v. North Carolina, 317 U.S. 287 (1942) (under full faith and credit, North Carolina must recognize Nevada divorce decree of North Carolina citizens legitimately domiciled in Nevada, even though conditions for divorce not satisfied under North Carolina law); Kenney v. Supreme Lodge, 252 U.S. 411 (1920) (Illinois court must enforce Alabama judgment in wrongful death action, even though action itself could not be brought in Illinois); Fauntleroy v. Lum, 210 U.S. 230 (1908) (Mississippi court must enforce Missouri judgment on gambling contract, even though contract would otherwise be illegal in Mississippi).

Recognition of an out-of-state judgment under full faith and credit may also bar further action by the enforcing state, which would otherwise alter the judgment. See, e.g., Yarborough v. Yarborough, 290 U.S. 202 (1933) (under full faith and credit clause, Georgia decree fixing father's permanent child support obligations is binding and bars another state from entertaining suit for additional contributions). But see Thomas v. Washington Gas Light Co., 448 U.S. 261, 270-72 (1980) (Stevens, J., plurality) (condemning state statutory provisions that direct extraterritorial effect of judgments as impermissible "delegation to the States of [the Supreme] Court's responsibility for the final arbitration of full faith and credit questions").

24. Even if states must occasionally enforce judgments that directly oppose their laws, see supra note 23 , such enforcement may ultimately preserve more than it threatens their integrity. States benefit substantially from full faith and credit: litigants cannot escape adverse judgments by simply leaving the state's territory. Conversely, the enforcement of a judgment at odds with a state's laws poses no real threat to its sovereign power. See Radin, supra note 1, at 24-35 (arguing that frustration experienced by states enforcing judgments at odds with their public policy is exaggerated because there is no real danger that enforcing state's policy will be nullified). 
problems where one state applies the laws of another. In the latter circumstance, a court may decide a case according to another state's law, even though the policy underlying that law conflicts with the policy of the forum state. This deference to the laws of the outside state is generally not considered harmful to the policies of the forum state, which benefits reciprocally from other states' deference to its own laws. The enforcement of judgments under another state's laws, like the application of the laws themselves, generally has no deleterious effect on the laws of the enforcing state.

\section{Intercircuit Enforcement}

While nations and even states have attributes of sovereignty-executive, legislative and judicial independence-the federal circuits belong to a single sovereignty. In contrast to state courts, their mandate is to interpret a single body of law-federal statutes and the United States Constitution. ${ }^{25}$ Though the circuits might have been structured differently-that is, as panels of a single jurisdiction, bound by one another's decisions-judges from different circuits have always been free to interpret federal law subject only to Supreme Court rulings. They owe no obedience to the coordinate courts of other circuits. ${ }^{28}$

This autonomy of federal circuit courts inevitably produces conflict. A

25. Of course, both state and federal courts may interpret state and federal laws. This Note, however, focuses on comparisons between the administration by states of state laws-either their own or those of other states-and the administration by federal courts of federal laws.

26. The history of the relationship between the federal circuit courts is difficult to trace. During the century-long reformation of the federal judicial system, discussion appears to have focused primarily on the role of the circuit courts in the effort simultaneously to reduce the onerous workload of the Supreme Court and to nationalize the federal system of a country with ever-expanding boundaries. The relationship between the circuits seems to have been a secondary concern, though it was not a problem of which the reformers were unaware. Some scholars have demonstrated that in devising the new judicial system, the architects of the federal judiciary used the knowledge gained from the different state judicial systems, among which were systems in which intermediate courts were bound by one another's rulings. The law-of-the-circuit system-in which circuit courts are not bound by rulings from other circuits-was thus not the inevitable structure of the federal judiciary. Note, Securing Uniformity in National Law: A Proposal for National Stare Decisis in the Courts of Appeals, 87 Yale L.J. 1219, 1224-36 (1978); see also F. FrankfuRTER \& J. LANDIS, The Business of THE SUPREME COURT 80-81 (1927).

The proposal for circuit courts of appeals that was supported by the American Bar Association seems presumptively to have permitted disagreement; indeed, this presumption is clear from objections to this proposal for reform. During the late 1880's, the American Bar Association drafted two plans aimed at alleviating the overloaded Supreme Court docket. The "minority" proposal would have divided the Supreme Court into panels, while the "majority" proposal postulated circuit courts of appeals. 3 Arguments and Speeches of William Maxwell Evarts 319-20 (S. Evarts ed. 1919) [hercinafter cited as ARGUMENTS AND SPEECHES]. Senator Evarts, who eventually sponsored the Circuit Courts of Appeals Act, ch. 517, 26 Stat. 826 (1891) [hereinafter cited as 1891 Actl, which created the current circuit courts, initially favored the "minority" proposal. A champion of the cause of uniform federal law, Evarts feared that circuit conflict was inevitable in a system of coordinate courts. Note, supra, at 1235 . Ultimately, though, Evarts recognized that his position lacked support and backed the circuit courts of appeals as a "second-best" reform. Id. at 1235-36. 
decision by the Supreme Court can resolve these differences, but since the Judiciary Act of 1925 made review of most cases merely discretionary, ${ }^{27}$ litigants and circuits have been unable to rely on the Supreme Court's eventual consideration of circuit conflicts. ${ }^{28}$ Even when the Court chooses to exercise its discretion, a substantial period of time often elapses between the emergence and resolution of intercircuit conflicts. This time lag preserves conflicts between circuits and produces, in effect, different bodies of law independently administered. Circuits thus begin to act like separate states, developing individual bodies of law. The coexistence of opposing interpretations of a single set of laws, though difficult to square with the uniformity expected of a federal judicial system, inevitably follows from the structure of our federal circuits. ${ }^{29}$

27. Act of Feb. 13, 1925, ch. 229, 43 Stat. 936. This Act is known as the "Judges' Bill" because it was drafted by a Committee of Supreme Court Justices. Stevens, The Life Span of a Judge-Made Rule, 58 N.Y.U. L. REv. 1, $10 \mathrm{n} .49$ (1983). The drafters designed the Bill primarily to reduce once again the weight of the Supreme Court docket, which, for the first time since the 1891 Act, supra note 26 , had swelled to an unmanageable size. The Judges' Bill alleviated the Court's burden by reallocating a substantial portion of cases from obligatory to discretionary review. Stevens, supra, at 10 n.52. For a general discussion of the Judges' Bill, see Frankfurter \& Landis, The Supreme Court Under the Judiciary Act of 1925, 42 HARV. L. REv. 1 (1928); Taft, The Jurisdiction of the Supreme Court Under the Act of February 13, 1925, 35 YALE L.J. 1 (1925).

28. To be sure, conflicts between the circuits command a high place in the hierarchy of cases meriting discretionary review under Supreme Court Rule 17:

A review on writ of certiorari ... will be granted only when there are special and important reasons therefor. The following .... indicate the character of reasons that will be considered.

(a) When a federal court of appeals has rendered a decision in conflict with the

decision of another federal court of appeals on the same matter . . . .

Sup. CT. R. 17. But the Court does not always grant certiorari in such cases. Thus in the $1981 \mathrm{Term}$, for example, Justice White, who is known to dissent whenever the Court denies certiorari to cases involving intercircuit conflict, wrote twelve such opinions. Hellman, Caseload, Conflicts, and Decisional Capacity: Does the Supreme Court Need Help?, 67 JudiCaTURe 29, 35 (1983). In such dissents Justice White typically affirms his view that resolution of intercircuit conflict constitutes a primary obligation of the Supreme Court. See, e.g., Novack Inv. Co. v. Setser, 454 U.S. 1064, 1065 (1981) (White, J., dissenting) (despite expanding size of its docket, the Supreme Court's "obligation to resolve [intercircuit] conflicts is just as pressing as is the need for a uniform rule of law"); Michael v. United States, 454 U.S. 950 (1981) (White J., dissenting) (Court should grant certiorari when circuit conflicts, ripe for resolution, would otherwise be left unresolved). The constantly increasing weight of the Supreme Court docket, however, arguably renders review of all intercircuit conflicts by the Court impossible. See generally Estreicher \& Sexton, supra note 8, at 696-704 (summarizing recent literature on problem of Supreme Court's workload).

Of course, Supreme Court decisions are not the only means for resolving circuit conflicts. Circuits may resolve conflicts themselves through en banc reversal when the accumulation of decisions persuades them that they erred in their initial holding. See, e.g., Copper Liquor, Inc v. Adolph Coors Co., 701 F.2d 542 (5th Cir. 1983) (per curiam) (overruling decision that conflicted with other circuits); United States v. Adamson, 700 F.2d 953, 956-65 (5th Cir.) (overruling statutory interpretation because it conflicted with several other circuits' interpretation and with other Fifth Circuit cases), cert. denied, 464 U.S. 833 (1983). Similarly, a change in legislation may render the subject of circuit conflict irrelevant. See, e.g., United States v. Gelb, 700 F.2d 875, 878-79 (2d Cir.) (enactment of Anti-Arson Act clarifies interpretation of ambiguous "anti-bombing" statute that divided circuits), cert. denied, 464 U.S. 853 (1983).

29. Though few would deny the desirability of uniform federal law, opinions vary widely concerning the lengths to which we should go to attain it. Some scholars and legislators advocate creating a new federal appellate court that would administer and hear appeals at a level between the circuit 
The law applied by different circuits, in contrast to that applied by different states, is at least nominally the same law. Thus, the enforcement of judgments between circuits poses a direct threat to uniformity and impartiality. Conflicts between states generally reflect contradictory public policies or decisions. But because circuits decide a single set of laws, conflicts between circuits create conflicting applications of a single set of laws -in effect, directly contradictory laws. States, recognizing extraterritorial judgments, may have to enforce judgments at odds with their public policy. ${ }^{30}$ But circuits may confront exactly opposite rulings on the same law coexisting within their borders.

courts of appeals and the Supreme Court. They argue that the weight of the Supreme Court docket, coupled with the presence of perennial intercircuit conflict, necessitates such an intermediate judicial body. During the 1970's two principal proposals were forwarded for a National Court of Appeals. Federal Judicial. Center, Report of the Study Group on the Gaseload of the Supreme CourT (1972) [hereinafter cited as FREUND REPORT] (proposing court that would screen cases for Supreme Court review and decide many intercircuit conflicts of importance insufficient to merit Supreme Court adjudication); UnIted States Commission on Revision of THe Federal Court Appellate System, Structure and Internal Procedures: Recommendations for Change (1975) [hereinafter cited as HRUSKA REPORT] (proposing court that would decide cases referred by Supreme Court subject to subsequent discretionary Supreme Court review). Some detractors of these proposals argue that a National Court of Appeals would impinge upon the constitutionally based powers of the Supreme Court, see, e.g., Black, The National Court of Appeals: An Unwise Proposal, 83 YALE L.J. 883 (1974); some fear that it would rob the Court of docket control, see, e.g., Blumstein, The Supreme Court's Jurisdiction-Reform Proposals, Discretionary Review, and Writ Dismissals, 26 VAND. L. REv. 895, 911-16 (1973); still others contend that the size of the Court's intercircuit conflict docket has been exaggerated and is still manageable, see, e.g., Hellman, supra note 28, at 35-37. See also Wallace, The Nature and Extent of Intercircuit Conflicts: $A$ Solution Needed for $a$ Mountain or a Molehill?, 71 CALIf. L. REv. 913 (1983) (arguing that uniformity of law should not necessarily be the single or even primary concern in administration of federal judicial system, and that conflicts are not intrinsically intolerable). A more recent proposal, championed by Chief Justice Burger, posits an Intercircuit Tribunal that would exist for five years, composed of Court of Appeals judges who would sit in panels. See generally Estreicher \& Sexton, supra note 8, at 684-89 (describing recent proposals); Burger, Annual Report, supra note 8 (describing and advocating Intercircuit Tribunal); Burger, Intercircuit Panel, supra note 8 (same).

Arguments for a more uniform federal law focus chiefly on the inequities among citizens that occur purely because of accidents of geography. "Where differences in legal rules applied by the circuits result in unequal treatment of citizens with respect to their obligations to pay federal taxes, their duty to bargain collectively or their liability to criminal sanctions, solely because of differences in geography, the circumstance is admittedly an unhappy one." HRUSkA REPORT, supra, at 5. The Hruska Report also emphasizes the insidious problems arising from potential but still unrealized conflicts: uncertainty in the law leads to years of repetitious litigation and burdens those who must regulate their activities by these unclear rules. Id.

Circuit courts themselves recognize the problems inherent in persistent, unresolved conflicts. Consequently, they typically consider with care the pertinent decisions of other circuit courts and the importance of the issue in question before rendering a decision that conflicts with that in another circuit. See, e.g., American Medical Int'l, Inc. v. HEW, 677 F.2d 118, 123 (D.C. Cir. 1981) (per curiam) ("W]hen cases presenting legal questions with national implications have arisen, this court has always considered itself obligated to subject the analyses of coordinate tribunals to close scrutiny, with the aim of producing a sound and well-reasoned decision") (footnote omitted). But circuit courts also acknowledge the value of conflicts. See, e.g., United States v. Anaconda Co., 445 F. Supp. 486, 496 (D.D.C. 1977) ("inquiry by other circuits should not be foreclosed; indeed, a conflict among the circuits could be a healthy matter").

30. The Restatement (Second) of Conflict of Laws $\S 103$ (1969) describes an exception to full faith and credit where enforcement of another state's judgment "would involve an improper interference with important interests of the [enforcing] State." Id. (emphasis added). Though courts fre- 


\section{An Example}

The following example illustrates the dilemma faced by a circuit court when it is asked to enforce another circuit's judgment on a matter of federal law. The EPA brings lawsuits against two national industrial corporations, $A$ and $B$, to enjoin them from continuing an industrial practice that is regulated by federal law. In the suit between $A$ and the government in Circuit 1, A wins. In the suit between B and the government in Circuit 2, the government wins. A has another plant in Circuit 2, and the government decides to take advantage of its favorable legal precedent in the case against $\mathrm{B}$ by bringing another action against $\mathrm{A}$, this time in Circuit 2:

\section{Circuit 1}

\section{A Wins}

time 1:

time 2:

time 3:

\section{Circuit 2}

\section{B Loses}

A (?)

The outcome of the government's third suit differs depending on the rule applied. Under a rule of full faith and credit, A's Circuit 1 success would have preclusive effect in Circuit $2 .^{31}$ Circuit 2 would then enforce simultaneously two directly conflicting judgments: B's defeat and A's victory against the government.

Under a rule of strict jurisdictional boundaries, on the other hand, A's victory in Circuit 1 would have no effect in Circuit 2. Instead, stare decisis would control: The suit against $A$ in Circuit 2 would follow the holding in the B case, which intervened as "hostile" precedent between the two suits against A. A would still enjoy victory in Circuit 1 , but it would

quently pay lip service to this exception in dicta, few actually apply it to overrule the presumption of full faith and credit afforded judgments from other states. See, e.g., Sangiovanni Hernandez v. Dominicana de Aviacion, 556 F.2d 611 (1st Gir. 1977) (reversing trial court's decision to apply public policy exception to res judicata, because difference in method for determining settlement in wrongful death action did not go to heart of enforcing forum's public policy); Somportex Ltd. v. Philadelphia Chewing Gum Corp., 318 F. Supp. 161, 168-69 (E.D. Pa. 1970) ("merely because the forum has a different rule of law, whether legislatively or judicially founded, does not automatically render the foreign law contrary to the public policy of the [enforcing] forum") (footnote omitted) affd, 453 F.2d 435 (3d Cir. 1971), cert. denied, 405 U.S. 1017 (1972). Even the Restatement acknowledges that the extent and application of this exception remain uncertain. Restatement (SECOND) of Confuict OF Laws $\S 103$ comments a \& b (1969). This exception, as embodied in the Restatement, is sharply and persuasively criticized in Note, Full Faith and Credit to Judgments: Law and Reason Versus the Restatement Second, 54 CALIF. L. Rev. 282 (1966).

31. Whether the technical rule of preclusion would be claim preclusion-res judicata-or issue preclusion-collateral estoppel-depends on how the cause of action is defined. Because the facts, though identical, occurred at two distinct times and places and gave rise to two separate lawsuits, these cases seem better categorized as two separate causes of action. Collateral estoppel would then preclude relitigation because the particular matter of law had been conclusively decided between the parties. 
have to modify its activities in Circuit 2 . Thus the same litigant would be subject to conflicting rules of law for identical plants.

Both rules violate the principle of uniformity and the underlying values of equity and judicial integrity. Under the first rule, the law is enforced according to the identity of the litigants and, therefore, is unevenly applied within a jurisdiction. ${ }^{32}$ This incidental distinction between litigants spurs strategies such as forum shopping and "racing to the courthouse" to secure a binding judgment-strategies that inhibit a circuit's ability to administer its own law. Governing law within a single circuit becomes uncertain, ${ }^{33}$ and faith in the judicial system diminishes.

Under the second rule, law is enforced according to geographic location. Consequently, a single litigant faces conflicting judgments on the same dispute. This rule preserves uniformity within a single circuit at the expense of comity within the federal system, leading to a paradoxical result: Full faith and credit ceases to govern interaction between coordinate circuit courts; they may freely ignore one another's judgments-a luxury unknown even to states, notwithstanding their sovereignty and independence-and give no credit to the principle of res judicata designed to avoid repetitious litigation. ${ }^{34}$

\section{The Proposal: A Rule of Intercircuit Enforcement of EXTRACIRCUIT JUDGMENTS}

The example given above rests on the premise that the dispute between the government and Corporation A persists even after they leave Circuit 1. Indeed, only in cases where some dispute persists might parties seek to enforce a judgment in another circuit. The problem of intercircuit enforcement of judgments is, therefore, limited to circumstances where a judgment has future effect. These cases generally fall into two categories. The first consists of judgments where the relief itself is prospective or continuing, such as injunctive orders or declaratory judgments. ${ }^{35}$ The second con-

32. Inconsistent judgments within a circuit may appear to be only a minor evil that necessarily results from the important preservation of a strict rule of res judicata. But when those inconsistent judgments determine the litigants' rights in every federal circuit, basic notions of fairness are threatened. In the example of two similar corporations, A and B, with plants in several circuits, A wins its initial suit and B loses. Because these judgments govern all of their plants, A may enjoy benefits grossly disproportionate to B's misfortunes. This unequal treatment exceeds the bounds of "minor" inequities incident to res judicata.

33. This uncertainty poses serious administrative problems and unnecessary cost for those who must regulate their activities according to the prevailing law. HRUSKA REPORT, supra note 29, at 19.

34. Litigation is particularly repetitious in this context because the legal questions relitigated arise under the same law.

35. Of course, for a fixed period of time-between pronouncement and enforcement of the judgment-even orders for damages are, in effect, prospective. Once a money judgment is paid, though, the problem ends. By contrast, equity relief generally involves the right to act or refrain from acting in some way. In enforcing a judgment for such distinctive relief, a court cannot help but look to the 
sists of cases where adjudication of an issue of law between the parties has later collateral estoppel effect; this final determination of law acts analogously to an injunction between the parties. Because prospectivity inheres in the problem of intercircuit enforcement, this Note looks to rules of prospective judgments from which to extrapolate a rule of federal res judicata that accommodates the special features of the federal circuits.

\section{A. Prospective Judgments and the Sunnen Rule}

Full faith and credit extends the single jurisdiction doctrine of res judicata to a multi-forum context. ${ }^{36}$ In a single jurisdiction, preclusion of prospective judgments is governed by the change in the law doctrine. ${ }^{37}$ This doctrine, as articulated by the Supreme Court in Commissioner v. Sunnen, ${ }^{38}$ accepts the premise that the finality of prospective orders entitles them to res judicata effect. ${ }^{39}$ But if a subsequent change in controlling legal principles ${ }^{40}$ renders the judgment obsolete or erroneous, the change in the law doctrine permits the enforcing court to modify the judgment. In Sunnen, for example, a taxpayer unsuccessfully invoked collateral estoppel against the Internal Revenue Service over an issue he had litigated and won in a previous tax year. The Court found that intervening decisions developing relevant legal principles might have produced a different result; it therefore disallowed the defense of collateral estoppel.

The Sunnen rule rests on the assumption that res judicata and collat-

substance of the case.

36. In the case of federal circuits, this adaptation raises challenging conceptual problems. Circuits fall into neither of the two categories that allow for an easy transition from the single to the multiple jurisdiction res judicata effect. If circuits acted as panels of a single jurisdiction, bound by one another's judgments, res judicata would automatically apply to all judgments as it does within a single circuit. If circuits were separate sovereign states as described above, see supra text accompanying notes $11-16$, the full faith and credit statute would merely preserve the preclusive effect given the judgment in the rendering forum. See supra note 13.

37. "Change in the law" is a subset of a general doctrine prescribing rules for modification of continuing orders, which refers not only to changes in law but also to changes in facts. See ResTATEMENT (SECOND) OF JUDGMENTS $\S 13$ comment c, at 135, \& Reporter's Note comment c, at 138 (1980). For purposes of this Note's analysis, however, only changes in legal principles are relevant.

38. 333 U.S. 591 (1948). Other cases have explored this concept with regard to specific types of judgments. For examples of injunctive orders where the law has subsequently changed, see System Fed'n No. 91 v. Wright, 364 U.S. 642 (1961) (change in controlling statutory law justifies modification of injunctive order, even when it is part of a consent decree); Griffin v. State Bd. of Educ., 296 F. Supp. 1178 (E.D. Va. 1969) (where intervening Supreme Court decision renders state statute constitutionally impermissible, prior prospective judgments under statute can be modified).

39. Of course, the change in the law rule applies only to continuing orders that are final. Their finality should not be misconstrued as tentative simply because they are sometimes referred to as " "modifiable' judgments." Restatement (SECOND) of Judgments $\$ 13$ Reporter's Note comment c, at 138 (1980). Their modifiability depends on whether the crucial circumstances change. Some specific judgments are inherently modifiable by statute or by the judgment itself. The Restatement cautions, however, that these generalizations may not apply to divorce and child custody judgments. Id. at 138-39.

40. Changes in either decisional or statutory law effect a change in the law for purposes of madifying judgments. See supra note 38 . 
eral estoppel should not estop all relitigation. Principles of preclusion "[are] not meant to create vested rights in decisions that have become obsolete or erroneous with time,"41 but merely to "prevent repetitious lawsuits over matters . . . which have remained substantially static, factually and legally."42 Sunnen draws the line between necessary and unnecessary relitigation at the point where estoppel creates inequities between litigants. "[G]ollateral estoppel must be used with its limitations carefully in mind so as to avoid injustice." 43 The Sunnen rule circumvents abuse by both defendant and plaintiff: A defendant who obtained a favorable judgment prior to a change in the law cannot avoid appropriate relitigation by invoking the defense of res judicata; a plaintiff cannot relitigate an unfavorable judgment unless statutory law changes or different parties litigate the issue with different results.

Sunnen's change in the law rule does not translate effortlessly into interfora enforcement of continuing judgments; moreover, its application differs in the interstate and intercircuit contexts. States adapt to this rule more easily than do circuits. Because states decide different sets of law, only the rendering state can change the law. When State B enforces State A's prospective judgment, it looks to State A's jurisprudence to determine whether the law has changed. No status of the law in State B bears on the judgment being enforced. Circuits, on the other hand, decide the same set of laws. Current jurisprudence leaves unclear whether a change in the rendering or enforcing forum, or both, constitutes a change in the law.

\section{B. The Proposed Rule}

Absent circuit conflicts, the common law rule of res judicata should have the same effect between circuits that it has between states. States give one another's judgments the effect they would have in the rendering forum. Section 1738 of 28 U.S.C. gives federal judgments the same full faith and credit. Thus, if the rendering and enforcing circuits share a common interpretation of the law, or if the enforcing circuit has rendered no decisions on point, ${ }^{44}$ res judicata should bar relitigation. Under these circumstances, res judicata correctly prevents repetitious lawsuits.

Where conflicts between the rendering and enforcing forums are present, however, they should be treated as changes in federal law for pur-

41. Sunnen, 333 U.S. at 599.

42. Id.

43. Id.

44. Mere enforcement of an extracircuit judgment does not bind the enforcing circuit to that interpretation of the law; on the contrary, when the enforcing circuit has not previously decided the issue, it is free to interpret that issue in future litigation between different parties, constrained only by a Supreme Court ruling. 
poses of modifying prospective orders. Hostile precedent in the enforcing forum would allow it to modify prospectively the judgment within its own boundaries. But because the modification would have no retrospective effect, the rendering forum need make no adjustment. By thus extending the Sunnen change in the law rule, which governs changes in law over time, to the intercircuit context of changes in law over geographical regions, a federal circuit court could at once follow the mandate of full faith and credit and retain control over its jurisdiction.

One important modification in the doctrine is needed for the intercircuit context-the requirement of an intervening change must be abolished. The rule that the change occurs after the initial judgment stems from the single jurisdiction premise of the rule of res judicata. In the intercircuit context that rule would produce a paradoxical result: The rendering circuit would retain the ability to change its law and modify the judgment prospectively; but the enforcing circuit that had contrary law preceding the extraterritorial judgment would have to recognize the judgment as preclusive, in effect, losing its power to exercise judgment over the case. ${ }^{45}$ Thus the enforcing circuit would have to give more weight to the judgment than would the rendering circuit.

The solution given here at once retains the advantages and mitigates the disadvantages of strict rules of preclusion and jurisdictional boundaries. Where no conflict or change in the law exists, res judicata governs the outcome and unnecessary litigation is avoided; but where conflict is present, the enforcing circuit may rehear the case and thus maintain control and uniformity within its own jurisdiction. This treatment of intercircuit conflicts accounts for the federal circuits being at once independent and part of a uniform system of law.

\section{The Analysis Applied}

The case of United States $v$. Stauffer Chemical Corporation ${ }^{46}$ makes plain the advantages of this solution.

\section{A. The Facts of Stauffer}

Stauffer Chemical Corporation had plants in both the Sixth and Tenth Circuits. During a twelve-month period, the EPA attempted to inspect these factories, accompanied by employees of a private firm, under the authority of the Clean Air Act. When Stauffer refused to admit the con-

45. The enforcing circuit would not be bound in subsequent cases to follow the hostile extracircuit judgment it enforces. But because its hostile precedent was decided prior to enforcement, it would not change its law after enforcement to a precedent unfavorable to the enforcing plaintiff.

46. 464 U.S. 165 (1984). 
tractors unless they signed an agreement not to disclose trade secrets, the EPA obtained an administrative warrant. Stauffer moved to quash the warrant, arguing that private contractors did not constitute "authorized representatives" within the meaning of the Act. This conflict between Stauffer and the EPA erupted and ended in litigation in identical form in both the Tenth and Sixth Circuits. ${ }^{47}$ Stauffer won in both the first appellate case, Stauffer $I$, in the Tenth Circuit ${ }^{48}$ and the second appellate case, Stauffer $I I,,^{49}$ in the Sixth Circuit. On the appeal of Stauffer II the Supreme Court, adhering to the classic rule of issue preclusion, held that collateral estoppel prevented the EPA from relitigating against Stauffer in the Sixth Circuit:

Tenth Circuit

\section{time 1: Stauffer Wins (Stauffer I)} time 2:

\section{Sixth Circuit}

\section{Stauffer Wins (Stauffer II)}

The majority chose not to address a further complicating fact raised in the briefs. Between the adjudication of Stauffer I and Stauffer II, the EPA litigated the same issue against another defendant, Bunker Hill, in the Ninth Circuit. ${ }^{50}$ The Ninth Circuit openly disagreed with Stauffer I, stating, "[w]e find the Tenth Circuit's interpretation unpersuasive," it held that the EPA had correctly implemented the statute. The intercircuit conflict created by Bunker Hill presented the following hypothetical question based on the Stauffer facts: had Stauffer II been in the Ninth Circuit and an intercircuit conflict between the Ninth and Tenth Circuits existed, would res judicata still preclude relitigation of the issue determined in Stauffer II?

47. The district court cases were: In re Stauffer Chem. Co., 14 Env't Rep. Cas. (BNA) 1737 (D. Wyo. 1980) (finding for Stauffer on merits), affd sub nom. Stauffer Chem. Co. v. EPA, 647 F.2d 1075 (10th Cir. 1981); United States v. Stauffer Chem. Co., 511 F. Supp. 744 (M.D. Tenn. 1981) (finding for EPA on merits), rev'd, 684 F.2d 1174 (6th Cir. 1982), affd, 464 U.S. 165 (1984).

48. Stauffer Chem. Co. v. EPA, 647 F.2d 1075 (10th Cir. 1981).

49. United States v. Stauffer Chem. Co., 684 F.2d 1174 (6th Cir. 1982), affd, 464 U.S. 165 (1984). Stauffer won this case, but three conflicting opinions by the panel leave the holding unclear and illustrate the confusion sparked by the Stauffer problem. Judge Weick held that collateral estoppel controlled the case; but he also reached the merits, finding for Stauffer on those grounds as well. Judge Jones concurred only with the collateral estoppel holding and would not reach the merits. He insisted that preclusion must be allowed in order to avoid inequity to Stauffer, whose plants and trade secrets would otherwise enjoy protection in one geographic area but not in another. Id. at 1190-92. Finally, Judge Siler voiced the opposite view. He argued that though collateral estoppel technically applied in this case, it should not be used to bar litigation where several circuits were deciding the same issue. Otherwise, he asserted, inequities to litigants-especially those in the same area-would result. He concurred with Judge Weick's opinion on the merits. Id. at 1192.

50. Bunker Hill Co. Lead \& Zinc Smelter v. EPA, 658 F.2d 1280 (9th Cir. 1981).

51. Id. at 1283. The district court decision in Bunker Hill had already been decided when the Tenth Circuit heard Stauffer I. In a footnote the Tenth Circuit "acknowledged" that different conclusions had been reach by the two courts. Stauffer Chem. Co. v. EPA, 647 F.2d at 1079 n.9. 
Tenth Circuit time 1: Stauffer Wins (Stauffer I) time 2: time 3:

\section{Ninth Circuit}

\author{
Bunker Hill Loses \\ Stauffer (?) (Stauffer II)
}

Though the majority opinion leaves the answer unclear, Justice White wrote a concurring opinion explicitly to address this issue. He explained that his concurrence on the actual facts was premised on the Sixth Circuit's lack of previous rulings on the statute. ${ }^{\mathrm{b} 2}$ Justice White concluded, however, that had Stauffer II been litigated in the Ninth Circuit as in the hypothetical variation, preclusion would be inappropriate because of the inequities that would result-Bunker Hill would be governed by one unfavorable rule of law while its neighbor and competitor Stauffer would enjoy the opposite, favorable one.

\section{B. The Proposed Rule and Stauffer}

The Supreme Court opinions and the three separate and conflicting opinions of the Sixth Circuit panel in Stauffer $I I^{\mathbf{s 3}}$ underscore the need for a cohesive rule of intercircuit enforcement of federal judgments. The solution proposed in this Note answers this need by providing a clear rule based on analysis of precisely those policy and equity concerns that inform the principle of preclusion. This solution would allow the court to apply a coherent analysis to reach the results specified by Justice White in both the actual and hypothetical Stauffer cases.

\section{Example One-The Facts of Stauffer}

According to the proposed rule and the actual facts, Stauffer would have won on the appeal of Stauffer II-res judicata would have barred relitigation of the case. The Sixth Circuit had no pre-existing contrary precedent, so no conflict analogous to a change in the law existed between the rendering and enforcing forums. Under Sunnen, short of statutory reform, the law changes only when other parties litigate the issue with different results. ${ }^{54}$ Without such a change, parties to the judgment have no opportunity to relitigate.

52. 464 U.S. at 178 (White, J., concurring).

53. See supra note 49.

54. This example shows that the proposed rule preserves the correct interplay between res judicata and stare decisis. See supre note 4. A losing party cannot relitigate an issue in an attempt to change the law. Under res judicata, she is precluded from relitigating. But if the court overrules its former decision when hearing the issue before other parties, the original parties may justly benefit from that change in the law under stare decisis: when they relitigate, the court is bound to deliver judgment according to the changed law.

According to the rationale of United States v. Mendoza, 464 U.S. 154 (1984), the United States 


\section{Example Two-The Hypothetical Variation}

If Stauffer II had been brought in the Ninth Circuit, which was in conflict with the Tenth Circuit, the judgment would be modifiable-Bunker Hill, the hostile precedent, would constitute a change in the law. In this variation, Stauffer II would be modified by the Ninth Circuit regardless of when Bunker Hill was decided: If Bunker Hill either (1) preceded Stauffer I or (2) followed Stauffer I but preceded Stauffer II, the rendering and enforcing circuits would be in conflict at the time the judgment was enforced.

A different circumstance would arise if Bunker Hill occurred after the enforcement of Stauffer II in the Ninth Gircuit. The Ninth Circuit could rehear Stauffer II and modify the judgment prospectively within its own borders. This modification is possible, however, only because Stauffer II is a prospective judgment ordering ongoing relief.

\section{Example Three-A Second Hypothetical Variation}

Significantly, the Ninth Circuit's modification of Stauffer II discussed in Example Two would not alter retrospectively or prospectively Stauffer's initial judgment in the Tenth Circuit. Suppose the EPA tried to take its favorable Ninth Circuit judgment (Stauffer II) back to the Tenth Circuit (Stauffer III) in an attempt to undo the ill effects of its initial defeat in Stauffer I. Stauffer I itself would act as the hostile precedent-the change in the law that would permit modification of the Ninth Gircuit judgment. ${ }^{\text {ss }}$

\section{Tenth Circuit}

Ninth Circuit

time 1: Stauffer Wins (Stauffer $l$ )

time 2:

Bunker Hill Loses

time 3:

time 4: Stauffer Wins (Stauffer III)

government should be excepted from the rule that only different parties can change the law. In Mendoza the Court held that because of its special role as a party, nonmutual collateral estoppel should not apply against the government. Arguably, then, the government may litigate an issue against another party in the same circuit to produce a different rule of law. But see Stieberger v. Heckler, 615 F. Supp. 1315 (S.D.N.Y. 1985) (enjoining government agency from intracircuit nonacquiescence). For a discussion of the implications of Mendoza and arguments against its holding, see Note, Collateral Estoppel and Nonacquiescence: Precluding Government Relitigation in the Pursuit of Litigant Equality, 99 HaRv. L. REv. 847 (1986).

55. This variation typifies the classic application of claim preclusion-the same cause of action cannot be relitigated. 


\section{Some Broader Implications of the Rule}

Two problems that arise in these hypothetical examples are more apparent than real.

\section{Inconsistent Judgments for the Same Litigants}

From Example Two it may appear that the proposed rule results in inconsistent judgments for a single litigant. As long as circuits can conflict, no solution achieves consistency in all cases; that is, no solution can simultaneously ensure similar treatment for similarly situated parties and the same treatment for a single party in different circuits.

Uniform treatment for a single party in all circuits, however, can be accomplished only by permitting intracircuit conflicts, which undermine both fairness and judicial integrity. Intracircuit conflict benefits disproportionately those litigants who happened to receive a favorable judgment initially and, conversely, punishes disproportionately those who did not. ${ }^{58}$ Such disparate results, in turn, encourage litigants to shop for circuits with favorable laws.

The proposed rule suspends the preclusive effects of a judgment only when the rendering and enforcing circuits conflict. It thus limits the opportunities for relitigation, therefore mitigating the potential for inconsistent judgments affecting a single litigant. By adjusting enforcement of judgments to take into account circuit conflicts, the proposal recognizes that such conflicts inhere in our federal system; ${ }^{.7}$ it also comports with the general policy that "percolation" of legal questions through circuit conflict furthers the development of federal law. ${ }^{58}$ Given the choice between neces-

56. See supra note 32 .

57. Those who argue for an intermediate appellate tribunal, however, contend that conflict within our unitary federal system can and should be corrected. See, e.g., Schaefer, Reducing Circuit Conflicts, 69 A.B.A. J. 452 (1983) (arguing that Supreme Court should exercise its supervisory powers to require that circuits be bound by rulings of other circuits as panels within a circuit are bound by rulings of other panels); Note, supra note 26 (arguing that Congress should reorganize circuits as panels of a single national court of appeals, so that an en banc ruling of one circuit binds all federal courts).

58. The value of allowing legal issues to percolate through the circuits' conflicting interpretations has long been recognized-and debated-by courts and commentators. Justice Stevens has recently noted that though "[i]t would be better . . . if federal law could be applied uniformly in all federal courts ...., experience with conflicting interpretations of federal rules may help to illuminate an issue before it is finally resolved." Stevens, Some Thoughts on Judicial Restraint, 66 Judicature 177,183 (1982). Borrowing Justice Brandeis's metaphor that likens states to "laborator[ies]" that "try novel social and economic experiments without risk to the rest of the country," New State Ice Co. v. Liebmann, 285 U.S. 262, 311 (1932) (Brandeis, J., dissenting), some advocates of percolation have described circuits as laboratories that experiment with the application and interpretation of federal law. Schaefer, supra note 57, at 454; see, e.g., Wallace, supra note 29 , at 929 . Circuit conflicts may be useful for testing the practical effect of new laws, especially those that regulate little understood technical industries and alert Congress to a need for statutory reform. See, e.g., American Medical Int'l, Inc. v. HEW, 677 F.2d 118, 122 (D.C. Cir. 1981) (per curiam) ("li]t can hardly be gainsaid that complex questions of national import can wholesomely and profitably be explored by more than a 
sary evils, the inconsistencies sometimes produced by the proposed solution are preferable to inconsistent treatment of different litigants in the same jurisdiction, especially when such inequities follow them throughout the federal circuits.

\section{Repetitive Litigation Between Circuits}

From Example Three it may appear that the proposed rule encourages relitigation back and forth between two circuits. This problem would be eliminated, however, by an acknowledged, stable rule of intercircuit enforcement of federal judgments. For example, if the EPA knew the Stauffer III judgment would be modified according to the hostile Stauffer I decision, ${ }^{\mathbf{b \theta}}$ it would never attempt to enforce a favorable Ninth Circuit judgment in the Tenth Circuit.

Indeed, far from encouraging repetitive litigation between circuits, the proposed solution may provide incentive for appeal to the Supreme Court. The EPA deliberately challenged Stauffer in a second circuit instead of appealing Stauffer I. While such relitigation or "nonacquiescence" by government agencies ${ }^{60}$ against different parties was arguably accepted by the Supreme Court in United States v. Mendoza, ${ }^{61}$ the companion case to

single court"); Western Oil \& Gas Ass'n v. EPA, 633 F.2d 803, 808 (9th Cir. 1980) (in area of environmental law, court considers itself free to disregard rulings of other circuits). And, consistent with the premise of our adversary process that analysis and debate leads ultimately to truth, conflicting circuit court opinions perform the vital function of briefing the Supreme Court. Lower court opinions "compel analysis and formulation of the issues in a controversy, sharpen responsibility in adjudication, and advise litigants and the appellate court of the factors that control decision." Frankfurter \& Landis, supra note 27, at 23. Moreover, they flag difficult issues for the Supreme Court. See, e.g., Train v. Natural Resources Defense Council, 421 U.S. 60, 75 (1975) ("It]he disparity among the Courts of Appeals rather strongly indicates that the question does not admit of an easy answer"); American Medical Int'l, 677 F.2d at 122 ("independent reconsideration of legal issues by the circuits can facilitate Supreme Court review by highlighting their complications and controversial aspects") (footnote omitted).

59. Analogous to the problem of multiple relitigation between circuits is the problem of multiple transfers under the doctrine of forum non conveniens. See generally Marcus, Conflicts Among Circuits and Transfers Within the Federal Judicial System, 93 YALE L.J. 677, 679-82 (1984) (describing operation of federal transfer statutes). In an effort to put an end to abuse of forum non conveniens, by which litigants repeatedly transferred their cases back and forth between circuits, the Supreme Court in Hoffman v. Blaski, 363 U.S. 335 (1960), restrictively interpreted the relevant statute. Justice Frankfurter, in dissent, argued that res judicata should control instead: Once the motion to transfer is argued and decided, he maintained, that decision should control as res judicata. Id. at 350. Some subsequent cases have adopted the dissent's approach, using either res judicata or law of the case to limit transfers between circuits. See, e.g., Hayman Cash Register Co. v. Sarokin, 669 F.2d 162, 166-70 (3d Cir. 1982).

60. Nonacquiescence refers to the policy sometimes adopted by government agencies to relitigate an issue of law, generally against different parties, after they have litigated the issue and lost. See generally Note, Administrative Agency Intracircuit Nonacquiescence, 85 ColuM. L.REv. 582, 584-89 (1985) (examples of nonacquiescence); Vestal, Relitigation by Federal Agencies: Conflict, Concurrence and Synthesis of Judicial Policies, 55 N.C.L. REv. 123 (1977).

61. 464 U.S. 154 (1984). Two basic themes dominate the Court's opinion: the importance of preserving the unique role of the government as a litigant and the importance of ensuring that difficult issues of law can percolate through the circuits. 
Stauffer, relitigation against the same party raises distinct and very serious problems. It frustrates a fundamental purpose of preclusion-protecting litigants from burdensome relitigation. ${ }^{62}$ And at least one court has suggested that such badgering violates due process. ${ }^{63}$ Relitigation against the same party, absent a compelling reason such as a change in the law, is not justifiable.

The proposed rule furthers the twin goals of avoiding needless litigation and resolving conflicts when they are ripe: The government is discouraged from relitigating against a single defendant when no intercircuit conflict exists. But where conflict persists because the law is not resolved, one of the parties has incentive to appeal and resolve the circuit split rather than relitigate. $^{.4}$

\section{Conclusion}

Absent dramatic restructuring of our federal system, circuit conflicts, however temporary, are inevitable. Though the interpretive independence of the federal circuits governs the respect they must accord one another's precedent, it leaves uncertain the respect they must accord one another's judgments. Despite the increasingly national nature of American business and the ease with which individuals move from place to place, no acknowledged rule defines the credit one circuit must afford another circuit's judgment on federal law when the enforcing and rendering circuits con-

The Supreme Court has outspokenly endorsed "percolation" of difficult issues through the circuits. See, e.g., E.I. du Pont de Nemours \& Co. v. Train, 430 U.S. 112, 135 n.26 (1977) ("It]his litigation exemplifies the wisdom of allowing difficult issues to mature through full consideration by the courts of appeals"). By limiting nonmutual collateral estoppel to suits between private parties, Mendoza underscores this view. In that case the government attempted to relitigate an issue on which it had lost in a different proceeding against another party. The Mendoza Court noted that "[a] rule allowing nonmutual collateral estoppel against the Government . . . would substantially thwart the development of important questions of law by freezing the first final decision rendered on a particular legal issue." Id. at 160 .

A principal advantage of circuit conflicts identified by the Mendoza Court is the time lapse between the emergence of intercircuit conflict and its resolution-a weakness in the system from the standpoint of many supporters of a National Court of Appeals or an Intercircuit Tribunal-which has the beneficial effect of preventing premature determination of an issue. Id. at 160 . Cf. Harlan, Thoughts at a Dedication: Keeping the Judicial Function in Balance, 49 A.B.A. J. 943, 944 (1963) (exhorting lawyers and judges to recognize the "catalytic" effect of time in the judicial and legislative processes).

62. The res judicata values of efficiency and equity clearly outweigh the benefits of government relitigation where the same parties are litigating the same issue. In these circumstances litigation is purely redundant. See supra note 34 . This balance shifts dramatically when the government relitigates an issue against different partics.

63. Continental Can Co. v. Marshall, 603 F.2d 590, 597 (7th Cir. 1979) ("it appears rather fundamental that the Government cannot, without violating due process, needlessly require a party to undergo the burdens of litigation").

64. Under these circumstances it is important that the Supreme Court exercise its power of discretionary review. Ironically, though the Court granted certiorari to Stauffer $I I$, a case whose history is riddled with disagreement between courts, see supra text accompanying notes $46-51$ \& note 49 , it decided the case on res judicata grounds rather than resolving the conflict. This decision is anguably correct insofar as the question on the merits was not ripe. 
flict. The two extreme approaches to this problem-always recognizing or never recognizing the extracircuit judgment-suffer from a twofold failure: because they fail to take into account the unique structure of the federal system, they also fail to achieve justice and, instead, indiscriminately mete out different treatment to similarly situated litigants. This Note proposes a judicially developed rule of intercircuit enforcement of judgments that achieves a middle ground between those estremes. Drawing on the Sunnen rule, the solution offered here likens the change in law over time to circuit conflicts where the "same" federal law changes across geographical regions-from one circuit to another. In the presence of such conflict, a federal circuit court should be permitted to modify a prospective federal judgment within its own circuit. 
